UDC 37.012.7:[372.891:376.42]

Tetiana Skyba

Sumy state pedagogical university named after A. S. Makarenko

ORCID ID 0000-0001-5346-1845

DOI 10.24139/2312-5993/2019.05/291-301

\title{
THE STUDY OF THE STATE OF SOCIO-ECONOMIC KNOWLEDGE FORMATION IN CHILDREN WITH INTELLECTUAL DISABILITIES (F-70)
}

The article describes essential characteristics of each quality of knowledge in accordance with the criteria for assessing the academic achievement of students with intellectual disabilities (F-70) in Geography. The basic criteria for studying the levels of students' socio-economic knowledge are defined and characterized by such characteristics as completeness, awareness, efficiency. Examples of diagnostic tasks that are adequate to the criteria and indicators that allow to obtain baseline data for determining qualitative characteristics of knowledge of socio-economic content of students with intellectual disabilities while studying the course "Geography of Ukraine" (Grade 9) are given. The content and main results of the search and diagnostic stages of the study are highlighted.

Key words: mentally retarded students, socio-economic knowledge, completeness of knowledge, awareness, efficiency of knowledge, ascertaining stage of research.

Introduction. The issue of formation of the key competences in children with special educational needs is becoming increasingly relevant in the light of reforming of the modern Ukrainian school. The concept of competence of a student with intellectual disabilities becomes important, which in turn is determined by many factors that make it possible to define the readiness of a child with special educational needs for life, his/her further personal development and active participation in society. Orientation of the educational process of a special school into competence education requires concrete practical results in development of a modern student with special educational needs. Formation in students with intellectual disabilities of understanding of the dynamics of geographical phenomena, processes, patterns at the local and regional levels occurs during the study of geography of the country of residence in the course "Geography of Ukraine" (Grade 9), which creates conditions for critical and substantive analysis and comparison of a subject geographical competence based on concretization and deepening of general geographical knowledge, skills and values.

Successful implementation of this task in special education is possible in the case of creation of appropriate psychological and pedagogical conditions and the use of effective methods of teaching students with intellectual disabilities on the basis of certain levels of formation of subject competences. Therefore, finding out 
the state of knowledge of socio-economic content of students with intellectual disabilities in the framework of the study of geography of Ukraine in the 9th grade of a special school requires determining the methodology and organization of the ascertaining stage of pedagogical research.

Analysis of relevant research. The studies of $\mathrm{S}$. Arkhanhelskyi, Yu. Babanskyi, V. Bespalko, and N. Kuzmina covered the issues of methodology and methods of pedagogical research. Separate aspects of research organization and processing of the obtained results were considered by $P$. Volovyk, S. Honcharenko, I. Pidlasyi and others. Theoretical and methodological foundations of socio-economic education of students with special educational needs in the study of geography are based on the results of the studies of a number of scientists, researchers and practitioners, among them: $\mathrm{H}$. Blech, V. Bondar, A. Vysotska, I. Dmytriieva, I. Yeremenko, V. Zolotoverkh, A. Kapustin, H. Mersiianova, V. Lykyi, V. Lypa, S. Myronova, L. Odinchenko, V. Synev, T. Skyba, E. Khokhlina and others. The works of T. Holovina, S. Dubovskyi, V. Lykyi, V. Lypa, L. Odinchenko, V. Sinov and others are devoted to the problem of forming the bases of economic knowledge, development of the issues of studying the levels of knowledge formation in mentally retarded children at some courses of Geography.

The aim of the article is to describe the methods, content and main results of the search and diagnostic stages of the ascertaining experiment, which envisaged the study of the state of socio-economic knowledge in students with intellectual disabilities at Geography lessons.

Research methods. In order to solve research problems and test hypotheses the methods of collecting information (survey of teachers and students, analysis of curriculum documentation, analysis of students' written and control works, study of plans and synopses of teachers' lessons, class journals, interviews with teachers and students); quantitative statistical methods; qualitative (analysis, synthesis, comparison) and interpretation (definition of patterns, formulation of conclusions and results) methods were used.

Research results. In the process of developing the AS of our research, the scientific-theoretical and practical experience of studying the level of knowledge of geographical and natural content in students with intellectual disabilities, covered in the scientific achievements of researchers $(\mathrm{H}$. Blech, $\mathrm{S}$. Dubovskyi, I. Cherepanova) was taken into account. We envisaged determining the levels and qualitative characteristics of formation of knowledge of socioeconomic content in the mentally retarded high school students, the complex value of which was determined on the basis of understanding the essence of 
these indicators of knowledge, defined in scientific research of H. Blech, T. Sak (completeness, correctness, awareness, efficiency). In our study, we have identified the essential characteristics of each quality of knowledge according to the criteria for assessing the educational achievements of students in Geography and related to the curriculum. Let's give their characteristics.

Completeness of knowledge. Level I - initial: fragmentary reproduction of the learning material. Level II - medium: reproduction of the material to the half of the volume. Partial detalization. Level III - sufficient: reproduction of the greater part of the material. The student has acquired geographical knowledge in the form of concepts. Level IV - high: the student has a formed system of geographical concepts provided by the curriculum.

Correctness of knowledge. Level I - initial: there is no knowledge. Level II - medium: the student gives unclear characteristics of geographical objects. Level III - sufficient: with mistakes and inaccuracy, the student reproduces part of the learning material independently without disclosing causeeffect relations. Level IV - high: the student has sufficient geographical knowledge and, under the guidance of the teacher, applies them to solve familiar standard situations. He does not make mistakes in reproduction of specific information, reveals conscious acquisition of learning material, explains, distinguishes the main and minor.

Awareness. Level I - initial: there is no knowledge. Level II - medium: the student reproduces the learning material in a fragmentary way, basically understands it as individual facts at the elementary level, cannot explain some material or reproduces it without disclosing cause-effect relations. Level III sufficient: the student shows knowledge and understanding of the basic provisions of the learning material in accordance with the requirements of the program, gives most of the definitions provided by the topic of the lesson. The answer is correct, but not well understood. Level IV - high: the student has mastered the basic ideas, concepts and categories of geographical science about the Earth and human economic activity. Under the guidance of the teacher he can explain the cause-effect relations in nature and economy. He attempts to give examples of interaction between nature and man.

Efficiency. Level I - initial: needs constant supervision and assistance from the teacher. Level II - medium: practical work is performed step by step according to the model, instructions and under the supervision of the teacher. Level III - sufficient: with the help of the teacher he is able to analyze, compare and draw elementary conclusions. He attempts to apply knowledge when performing tasks on a sample, in familiar situations. Level IV - high: 
independently and correctly performs similar tasks of practical direction (filling of outline maps, drawings of tables, diagrams, etc.). The new task is done with little help from the teacher.

After determining essential characteristics of the criteria and levels of socio-economic knowledge of students with intellectual disabilities, we turned to the search for diagnostic tools that would provide us with information we need to analyze. We determined formation of knowledge of socio-economic content in the mentally retarded high school students by the level of achievement of the qualitative indicators of knowledge presented in the study, distributed according to the initial, medium, sufficient, and high levels. We used specially selected tasks to identify each of them. In turn, each series of tasks was presented with 4 tasks to determine individual indicators (completeness, correctness, awareness, efficiency). Therefore, each respondent was required to complete 4 tasks in 4 series (16 tasks).

The experimental study involved 84 high school students of 9th grade with a diagnosis "Mild mental retardation" (F-70) of special schools in Lviv, Poltava, Sumy, Kharkiv, Donetsk, Zhytomyr regions. The study was conducted in 2016-2017. The analysis of the acquisition by students of the geographical material proposed by the curriculum was carried out in natural conditions that did not disturb the educational process: in the classrooms where children were usually taught, under the patronage of classroom teachers. When needed, children were provided with verbal, general or practical assistance.

The study of documentation of the education institutions allowed determining the age and qualitative composition of students: students aged 15-17 years, had impaired intellectual development of mild degree (F-70).

Detection of the actual state of knowledge by the indicator of correctness was carried out on the basis of analysis of the tasks of open and closed type, completing of which envisaged choosing one correct answer to the question asked, giving the definition. Therefore, the children needed to identify enterprises that are related to the production and non-production sphere; to define the concept of "manpower"; to determine specialization of sheep breeding. According to our plan, the number of correct answers will be expressed in points: one correct answer -1 point. High school students did not have much difficulty in completing Task 1 series, although, 8,5\% did not perform it, $10 \%$ did it with errors. The answers were correct in $23 \%$ of respondents, $51 \%$ of schoolchildren chose two answers, one of them incorrect, a common mistake $(5,2 \%$ of papers) was the choice of all answers to the test task. Having processed the results, we came to the following conclusions: 62 students (18,5\%) completed the tasks of 
the first series at the initial level. At the medium - 190 students $(56,5 \%)$, sufficient -62 students $(18,5 \%)$, high -22 students $(6,5 \%)$.
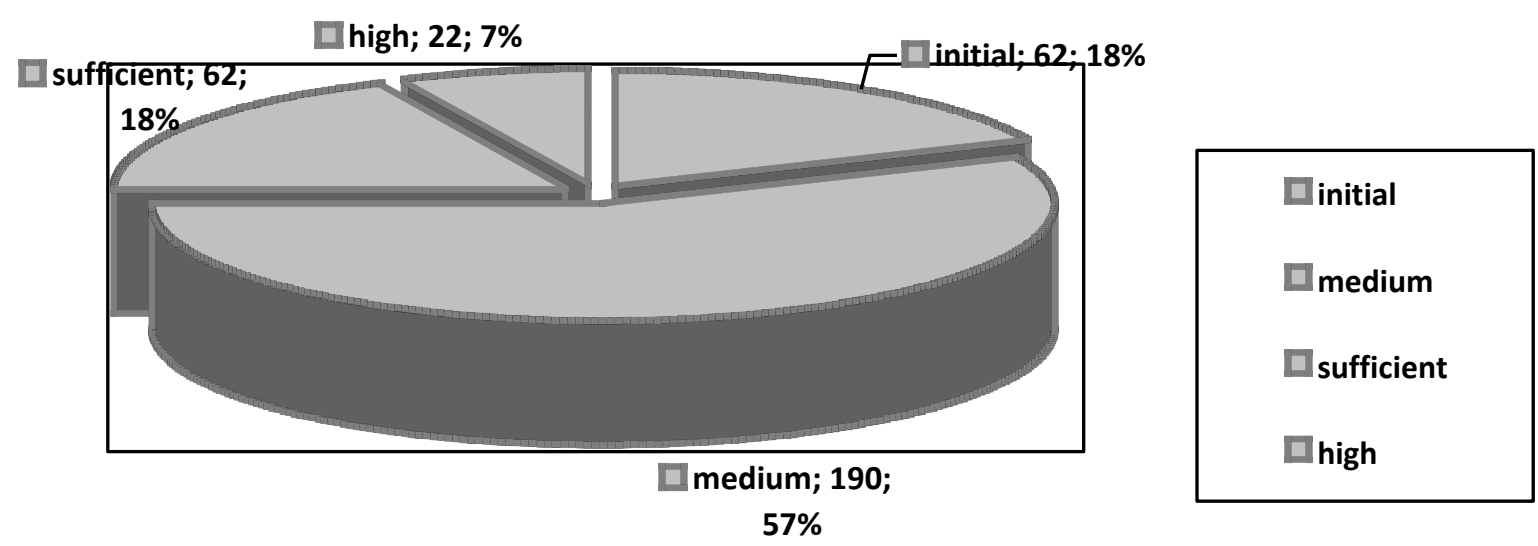

Fig. 1. Chart with indicators of levels of socio-economic knowledge formation in terms of correctness

Fulfilling tasks in terms of completeness required the ability to formulate definitions of concepts on topics "Population. Manpower", "Livestock of Ukraine", to explain the concept of "economy of the country", to indicate its main industries, to name the main branches of the forest industry, to know the main environmental problems associated with operation of thermal power plants.

Having calculated the answers, we obtained the following results: $51 \%$ of the students formulated the concept of "manpower" conditionally correctly. $4 \%$ of respondents provided more detailed and accurate definitions, adding all the essential characteristics that should have been formulated in children at the end of the study.

In order to identify the completeness of acquired knowledge, students were asked to name the main sectors of the forest industry. According to our plan, the students had to name the leading industries: logging, woodworking, pulp and paper and forestry. $5 \%$ of the students correctly completed the task, $25 \%$ identified only three branches, 53,6 \% named two branches correctly, while they called construction and chemical industries, $17 \%$ of respondents refused to complete the task.

The analysis of the obtained results leads to the conclusion about unconsciousness of memorizing the learning material for the mentally retarded high school students, the lack of focus of the students on the essential features and specificity of the studied industries.

In order to perform the following tasks, in particular, for defining concepts the students should be able to establish cause-effect relations. Thus, 
$10 \%$ of respondents said that the task was quite difficult: children refused to do it, $50 \%$ of students provided incomplete definitions, and sought help from teachers, $19 \%$ of children gave a complete definition of the concept, and only 5 $\%$ performed it correctly and without outside intervention. .

After calculating the average indicators of the level of knowledge of socioeconomic content in terms of completeness of knowledge, we found out that: at the initial level there were 64 students (19\%), at medium - 200 students (50\%), at sufficient -58 children $(17,2 \%)$, at high -14 respondents $(4,1 \%)$.

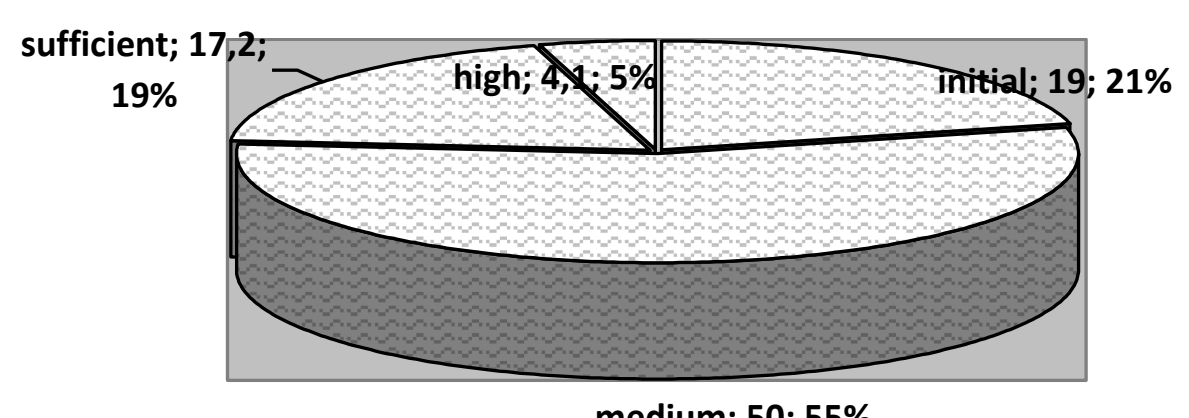

medium; 50; 55\%

Fig. 2. Chart with indicators of the levels of socio-economic knowledge formation in terms of completeness

At the next stage of the experiment, in order to determine the awareness of knowledge of socio-economic content were worked out the tasks, which provided us with information about knowledge on the main branches of the fuel and energy complex, students' understanding of the relationship between the enterprise and belonging to a particular industry of Ukraine. Before completing the tasks of this series, respondents were provided with detailed instructions, repeated as needed, and some students were provided with examples. At the high level, $6 \%$ of students completed the task of systematization of previously acquired knowledge. $12 \%$ of respondents completed this task at a sufficient level: they identified the components of the fuel and energy complex of Ukraine, its components. At the same time, some of the respondents made their choices unconsciously. $61 \%$ of high school students provided answers that were incomplete (medium level). $10 \%$ of students refused to complete this task, arguing that there was no interest, difficulty and complexity of the task.

The task of establishing the logical sequence (connection) in the components of the agro-industrial complex of Ukraine was somewhat difficult in terms of understanding the algorithm of execution. $19 \%$ of students completed the task at the initial level. $10 \%$ left it unfulfilled, $2 \%$ still tried to explain the value 
of the components. Students were unable to establish connections and relationships between the proposed logical sequence components. $7 \%$ constantly sought help from teachers, needed control over task performance, misplaced components. $16,7 \%$ of students completed this task at a sufficient level. Children almost independently, and in most cases correctly called the sequence of arrangement of components, practically did not require additional explanations from adults. No child has completed this task at the high level (0\%).

In order to identify the level of awareness of the knowledge gained, high school students needed to classify or match the objects of national economy.

The completion of the second series of tasks for determining the level of knowledge awareness showed that only $2 \%$ of students did it consciously (high level), $16 \%$ made insignificant mistakes (sufficient level), $63 \%$ did not understand cause-effect relations without supervision and counseling of teachers, $19 \%$ of respondents completed this task at the initial level.

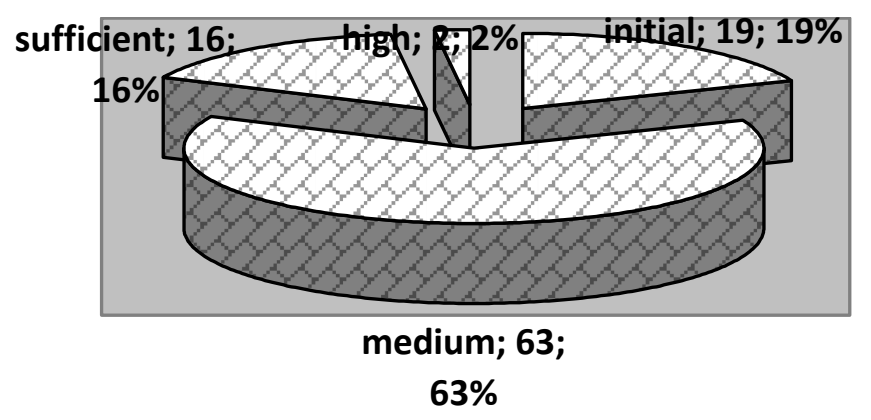

Fig. 3. Chart with indicators of the levels of socio-economic knowledge formation in terms of awareness

The use of knowledge is defined by didactists as one of the characteristics that reflect the quality of the knowledge obtained. In the framework of our study, mentally retarded high school students were offered the task of completing tables, identifying economic links between Ukrainian industries, reading and analyzing geographical maps of the atlas.

This series of tasks did not cause significant difficulties for $21 \%$ of students: the children quickly understood the sequence of their implementation, gave correct answers, did not require pedagogical support. 33 $\%$ of students used the knowledge they received with little reliance on the help of adults, understood the requirements made to them, provided correct answers. However, there were students (5\%) who did not perform the tasks due to increased fatigue of children, did not understand the instructions of step-by-step tasks, even after repeated explanations by their instructor $-5 \%$. 
The data obtained from the processing of children's responses to this series of tasks indicate that a small number of schoolchildren $(26,8 \%)$ have knowledge of socio-economic content at a sufficient level, understand their purpose, operate them, correctly apply them in practice. In turn, the majority of students $(47,6 \%)$ require the use of individual methods of teaching, detailing algorithms for completing tasks, strengthening the work of teachers in the formation of awareness of knowledge of socio-economic content in the study of some topics.

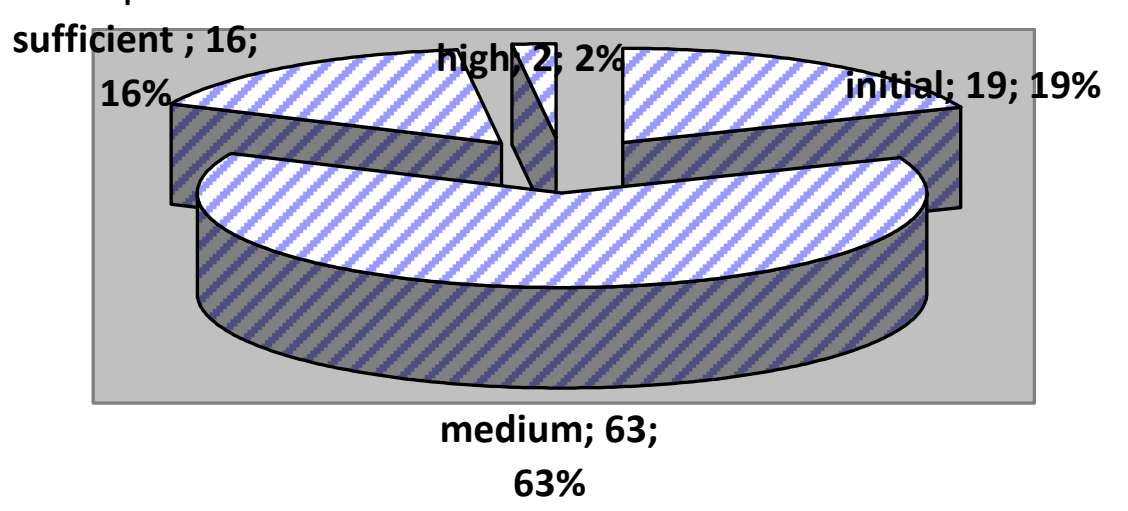

Fig. 4. Chart with indicators of the levels of socio-economic knowledge formation in terms of efficiency

Our study, aimed at identifying the levels of socio-economic knowledge formation in students with mental retardation in terms of completeness, correctness, awareness and efficiency, shows that $17,7 \%$ of students who participated in the survey have I (initial) level of knowledge. 53,6 \% of students who were able to reproduce part of the learning material without disclosing cause-effect relations, to give indistinct characteristics of geographical objects, to fulfill partially the tasks of practical content (on filling outline maps, drawing up schemes) with the help of teachers, correspond to II (medium) level of knowledge formation. $19 \%$ of respondents have III (sufficient) level of socioeconomic content knowledge formation. The students demonstrated knowledge and understanding of the basic provisions of the learning material in accordance with the requirements of the current program. The students' answers were partly correct, but they lacked awareness. The students demonstrated their ability to use cartographic material. Attempts were made to analyze, compare, and draw elementary conclusions.

A small number of students ( $8,6 \%$ ) corresponded to IV (high) level of knowledge formation. It can be stated that the students demonstrated the socioeconomic knowledge at the sufficient level, and under the guidance of the teacher 
applied them to solve familiar standard situations; tried to explain the causeeffect relations in nature and national economy, and give examples of the interaction between nature and man; had a sufficient level of using geographical nomenclature and map; independently performed tasks that required efficiency and awareness, new tasks were performed with little help from the teacher.

Conclusions. Substantiation of the methodology and organization of the AS of the study provided the opportunity to select tasks that correspond to diagnostic criteria and indicators that allowed to obtain baseline data to determine qualitative characteristics of knowledge of socio-economic content in students with intellectual disabilities. The results of our study confirm the need to study the specifics of the use of methods, forms, tools and techniques for the formation of socio-economic knowledge in students with intellectual disabilities during the study of the course "Geography of Ukraine" (Grade 9), professional training and readiness of teachers of special schools to work in this direction.

\section{REFERENCES}

Блеч, Г. О. (2007). Дидактичні умови забезпечення якості знань з природознавства у розумово відсталих учнів (дис. канд. пед. наук: 13.00.03). Київ (Blech, Н. A. Didactic conditions for the quality of knowledge in Science in the mentally retarded students (PhD thesis). Kyiv).

Одинченко, Л. К., Скиба, Т. Ю. (2015). Географія. Навчальні програми для 6-9 класів спеціальних загальноосвітніх навчальних закладів для розумово відсталих dimeй. Режим доступу: http://mon.gov.ua/activity/education/zagalnaserednya/osvita-osib-z-osoblivimi-potrebami/navchalni programi.html (Odynchenko, L. K, Skyba T. Yu. (2015). Geography. Educational programs for 6-9 classes of special secondary schools for children with mental retardation. Retrieved from: http://mon.gov.ua/activity/education/zagalna-serednya/osvita-osib-z-osoblivimipotrebami/navchalni-programi.html.

Одинченко, Л. К., Скиба, Т. Ю. (2018). До питання активізації пізнавальної діяльності дітей з порушенням інтелектуальної діяльності на уроках курсу «Географія України». Педагогічні науки: теорія, історія, інноваційні технології, 4, 417-426 (Odynchenko, L. K., Skyba, T. Yu. (2018). To the problem of activation of the cognitive activity of mentally retarded students at the lessons of the course "Geography of Ukraine". Pedagogical sciences: theory, history, innovative technologies, 4, 417-426).

Скиба, Т. Ю. (2016). До проблеми формування знань географічного змісту у учнів 3 інтелектуальними порушеннями. Науковий часопис НПУ імені М. П. Драгоманова. Серія 19: Корекційна педагогіка та спеціальна психологія, 143-148 (Skyba, T. Yu. (2016). To the problem of formation of knowledge of the geographical content of students with intellectual disabilities. Scientific journal of N. P. Drahomanov NPU. Series 19: Correctional Pedagogy and Special Psychology, 143-148).

Староста, В., Товканець, Г. (2015). Методологія та методи науково-педагогічних досліджень, 64 (Starosta, V., Tovkanets, H. (2015). Methodology and methods of scientific and pedagogical research, 64). 


\section{АНОТАЦІЯ}

Скиба Тетяна. Вивчення стану сформованості соціально-економічних знань у дітей з порушеннями інтелектуального розвитку (F-70)

у статті проаналізовано роботи науковців з питань методології ma методики педагогічних досліджень, їх організації й обробки отриманих результатів, окремих аспектів формування знань соціально-економічного змісту учнів із особливими освітніми потребами.

Подано сутнісні характеристики компонентів категорії «знання» відповідно до критеріїв оцінювання навчальних досягнень учнів із порушенням інтелектуального розвитку (F-70) та змісту діючих навчальних програм з географії для спеціальних шкіл для розумово відсталих учнів.

Для кожної зі складових показника «знання» (повнота, правильність, усвідомленість, дієвість) визначено й описано чотири рівні (початковий, середній, достатній, високий) сформованості соціально-економічних знань. здійснена характеристика основних критеріїв дослідження.

Описано організацію і методику проведення педагогічного експерименту, надано якісну характеристику контингенту респондентів, визначено перелік закладів загальної середньої освіти.

Наведено приклади діагностичних завдань, які дозволили отримати вихідні дані для визначення якісних характеристик знань сочіально-економічного змісту в учнів із порушеннями інтелектуального розвитку в межах вивчення курсу "Геограрія України» (9 клас). Так, виявлення фактичного стану наявності знань за показниками правильності, повноти, усвідомленості та дієвості здійснювалося на основі аналізу завдань відкритого й закритого типів, виконання яких передбачало обрати одну правильну відповідь на поставлене запитання, дати визначення поняття, заповнити табличю, скласти схему, заповнити контурну карту, установити взаємозалежні зв'язки.

здійснено аналіз якості виконання завдань учнями, наведено середні показники рівнів срормованості знань соціально-економічного змісту за такими компонентами, як: правильність, повнота, усвідомленість та дієвість.

Аналіз отриманих результатів дозволив констатувати необхідність вивчення питання специфіки використання вчителями географії спеціальних икіл методів, форм, засобів та прийомів формування соціально-економічних знань в учнів із порушеннями інтелектуального розвитку під час вивчення курсу «Географія України» (9 клас), продесійної підготовки та готовності педагогічних працівників до роботи в даному напрямі.

Ключові слова: розумово відсталі учні, сочіально-економічні знання, повнота знань, усвідомленість, дієвість знань, констатувальний етап дослідження.

\section{PEЗЮME}

Скиба Татьяна. Изучение состояния сформированности социальноэкономических знаний у детей с нарушениями интеллектуального развития (F-70).

В статье даётся характеристика составляющих компонентов категории «знание» в соответствии с критериями оценивания учебных достижений по географи для учащихся с нарушениями интеллектуального развития (F-70). Определены и охарактеризованы основные условия исследования уровней срормированности социально-экономических знаний учащихся по таким составляющим, как: правильность, полнота, осознанность, действенность. Приведены примеры диагностических заданий, адекватных критериям и показателям, которые позволили получить исходные данные для определения качественных характеристик знаний 
социально-экономического содержания у учащихся с нарушениями интеллектуального развития в рамках изучения курса «География Украины» (9 класс).

Ключевые слова: умственно отсталые учащиеся, сочиально-экономические знания, полнота знаний, осознанность, действенность знаний, констатирующий этап исследования

УДК 376.3

Ірина Чистякова

Сумський державний педагогічний університет імені А. С. Макаренка

ORCID ID 0000-0001-8645-510X

DOI 10.24139/2312-5993/2019.05/301-315

\section{СТРУКТУРНО-ЛОГІЧНА МОДЕЛЬ ВИХОВАННЯ ДІТЕЙ ДОШКІЛЬНОГО ВІКУ 3 ОСОБЛИВИМИ ОСВІТНІМИ ПОТРЕБАМИ В СПЕЦІАЛЬНИХ ЗАКЛАДАХ ОСВІТИ}

у статті представлено розроблену автором модель виховання дітей дошкільного віку із затримкою психічного розвитку в спечіальних закладах освіти, яка включає реалізацію послідовно структурованих компонентів (цільовий, теоретикометодологічний, змістово-процесуальний та очінно-результативний блоки), змістове наповнення яких уточнює інформачійний образ прочесу, що моделюється. Запропонована модель покликана забезпечити безперервність процесу виховання дошкільників із затримкою психічного розвитку в спеціальних закладах освіти. Доведено, що виховна робота з дітьми дошкільного віку $\epsilon$ обов'язковою складовою освітнього процесу в спеціальному закладі освіти. Цей вид педагогічної діяльності використовується для створення середовища, необхідного для всебічного розвитку дитини.

Ключові слова: виховання, вихованість, діти дошкільного віку, затримка психічного розвитку, спеціальний заклад освіти, модель виховання.

Постановка проблеми. Виховна робота з дітьми із затримкою психічного розвитку надзвичайно актуальна в сучасному світі, оскільки в даний час спостерігається збільшення числа дітей із проблемами в психічному розвитку, більшість із них відчувають труднощі в адаптації та соціалізації, у засвоєнні програми закладу дошкільної освіти (ЗДО). Одна з важливих проблем освіти сьогодні - розвиток нових підходів у виховній роботі з дітьми з особливими освітніми потребами (ООП). Увага до проблем виховної роботи з дітьми з ООП з боку держави, що проявляється в законодавчих актах, спрямованих на всебічну допомогу таким дітям, створення необхідних умов для постійного розвитку й удосконалення виховного процесу в закладі дошкільної освіти, а також здійснення закладом дошкільної освіти соціального замовлення батьків (законних представників) на виховання й навчання дітей з ООП, $є$ мотивацією до пошуку доцільних форм і методів виховної роботи з дітьми з ООП у закладі дошкільної освіти. 